\title{
Development of the insulin secretion mechanism in fetal and neonatal rat pancreatic B-cells: response to glucose, $\mathrm{K}^{+}$, theophylline, and carbamylcholine
}

\author{
A.C. Mendonça ${ }^{1}$, \\ E.M. Carneiro', \\ J.R. Bosqueiro ${ }^{3}$, \\ S.C. Crepaldi-Alves ${ }^{3}$ \\ and A.C. Boschero ${ }^{1}$
}

\author{
1Departamento de Fisiologia e Biofísica, Instituto de Biologia, \\ Universidade Estadual de Campinas, Campinas, SP, Brasil \\ ${ }^{2}$ Departamento de Educação Física, Instituto de Biociências, \\ Universidade Estadual Paulista, Rio Claro, SP, Brasil \\ ${ }^{3}$ Departamento de Educação Física/Ciências Biológicas, \\ Universidade Estadual Paulista, Bauru, SP, Brasil
}

\section{Correspondence \\ A.C. Boschero \\ Departamento de Fisiologia e \\ Biofísica, Instituto de Biologia \\ Universidade Estadual de Campinas \\ 13083-970 Campinas, SP \\ Brasil \\ Fax: 55 (019) 289-3124}

Research supported by FAPESP, CNPq, CAPES, and FINEP-PRONEX.

Received September 9, 1997

Accepted March 18, 1998

\section{Abstract}

We studied the development of the insulin secretion mechanism in the pancreas of fetal (19- and 21-day-old), neonatal (3-day-old), and adult (90-day-old) rats in response to stimulation with 8.3 or $16.7 \mathrm{mM}$ glucose, $30 \mathrm{mM} \mathrm{K}{ }^{+}, 5 \mathrm{mM}$ theophylline (Theo) and $200 \mu \mathrm{M}$ carbamylcholine (Cch). No effect of glucose or high $\mathrm{K}^{+}$was observed on the pancreas from 19-day-old fetuses, whereas Theo and Cch significantly increased insulin secretion at this age ( 82 and $127 \%$ above basal levels, respectively). High $\mathrm{K}^{+}$also failed to alter the insulin secretion in the pancreas from 21-day-old fetuses, whereas $8.3 \mathrm{mM}$ and 16.7 $\mathrm{mM}$ glucose significantly stimulated insulin release by 41 and $54 \%$ above basal levels, respectively. Similar results were obtained with Theo and Cch. A more marked effect of glucose on insulin secretion was observed in the pancreas of 3-day-old rats, reaching 84 and $179 \%$ above basal levels with $8.3 \mathrm{mM}$ and $16.7 \mathrm{mM}$ glucose, respectively. At this age, both Theo and Cch increased insulin secretion to close to twotimes basal levels. In islets from adult rats, $8.3 \mathrm{mM}$ and $16.7 \mathrm{mM}$ glucose, Theo, and Cch increased the insulin release by 104, 193, 318 and $396 \%$ above basal levels, respectively. These data indicate that pancreatic B-cells from 19-day-old fetuses were already sensitive to stimuli that use either cAMP or $\mathrm{IP}_{3}$ and DAG as second messengers, but insensitive to stimuli such as glucose and high $\mathrm{K}^{+}$that induce membrane depolarization. The greater effect of glucose on insulin secretion during the neonatal period indicates that this period is crucial for the maturation of the glucose-sensing mechanism in B-cells.
Key words

- Rat islet cell

- Glucose

- Pancreatic islets

- Carbamylcholine

- Theophylline

- Potassium

- Insulin secretion 


\section{Introduction}

Maturation of the insulin release mechanism in mammals occurs during the perinatal period of life. In rodents, the poor secretory response to nutrient secretagogues during the fetal period is rapidly converted to an adult response within a few days after birth (1). Despite some early controversial data, it is generally accepted that glucose starts to stimulate insulin secretion in the late stages of the gestational period (2-4); in rats, this occurs at precisely 19.5 days of fetal life (5). The insulin response at this age is monophasic and is not blocked by $\mathrm{Ca}^{2+}$ antagonists (4). A clear biphasic pattern of insulin secretion in response to glucose is detected only three days after birth, although at this age the insulin secretion is still well below the adult response (5).

In adult B-cells, the molecular mechanism underlying glucose-induced insulin secretion involves different steps. First the inhibition of $\mathrm{K}^{+}$efflux through $\mathrm{K}^{+}{ }_{\text {ATP }}$ channels, which is modulated by glucose metabolism and leads to membrane depolarization. This is followed by an increase in the cytosolic $\mathrm{Ca}^{2+}$ concentration as a result of membrane depolarization and $\mathrm{Ca}^{2+}$ influx through L-type $\mathrm{Ca}^{2+}$ channels $(6,7)$. Since $\mathrm{K}^{+}{ }_{\text {ATP }}$ is already present and operative in fetal B-cells (8), it has been suggested that the reduced insulin secretion in response to glucose reflects the uncoupling between glucose metabolism and membrane cell depolarization in these cells (9). This aspect is still a matter of debate (10-12). Glucose-stimulated secretion is also modulated by neurotransmitters and hormones involving the phospholipase $\mathrm{C}$ and adenylylcyclase pathways $(6,7)$.

In the present study we have compared the insulin secretion of fetal, neonatal and adult rat $\mathrm{B}$-cells in response to glucose, $\mathrm{K}^{+}$, theophylline and carbamylcholine. Insulin secretion in response to stimuli that involve membrane cell depolarization (glucose and high $\mathrm{K}^{+}$) occurred at the end of the fetal period, although the greatest increase in glucose-induced insulin secretion occurred after birth. Theophylline and carbamylcholine, which increase the cAMP and the $\mathrm{IP}_{3}$ and DAG content of pancreatic islet cells, respectively, potentiated insulin secretion after 19 days of fetal life.

\section{Material and Methods}

\section{Animals and pancreatic tissue}

Fetal (19- and 21-day-old), neonatal (3day-old) and adult (90-day-old) rats were used. The fetal ages were determined by counting the days after the presence of sperm was detected in vaginal smears following overnight mating. The pancreas from fetal and neonatal rats was reduced to approximately $0.5 \mathrm{~mm}^{3}$ by slicing. Isolated islets from adult rats were obtained by collagenase digestion. The rats were killed by decapitation.

\section{Insulin secretion}

To study insulin secretion, pancreatic tissue from fetal and neonatal rats (3-4 fragments/group), and adult islets (5/group) were first incubated for $45 \mathrm{~min}$ at $37^{\circ} \mathrm{C}$ in $0.75 \mathrm{ml}$ of Krebs-bicarbonate buffer of the following composition: $115 \mathrm{mM} \mathrm{NaCl}, 5 \mathrm{mM} \mathrm{KCl}$, $2.56 \mathrm{mM} \mathrm{CaCl}_{2}, 1 \mathrm{mM} \mathrm{MgCl}, 24 \mathrm{mM}$ $\mathrm{NaHCO}_{3}, 5.6 \mathrm{mM}$ glucose, supplemented with $3 \mathrm{mg}$ of $\mathrm{BSA} / \mathrm{ml}$ and equilibrated with a mixture of $95 \% \mathrm{O}_{2}-5 \% \mathrm{CO}_{2}, \mathrm{pH}$ 7.4. This medium was then replaced with fresh buffer and the fragments and islets were incubated for $1 \mathrm{~h}$ in the presence of increasing concentrations of glucose (2.8-16.7 mM). In another series of experiments, the fragments and islets were incubated in the presence of $5.6 \mathrm{mM}$ glucose with the medium also containing $30 \mathrm{mM} \mathrm{K}^{+}, 5 \mathrm{mM}$ theophylline, or $200 \mu \mathrm{M}$ carbamylcholine. The insulin content in the supernatant of each sample and the insulin extracted from the fragments and 
islets at the end of the incubation period were measured by radioimmunoassay as previously described (13), using rat insulin as standard. Since the amount of endocrine pancreas varied considerably between the fragments used, insulin release was expressed as percent of the total fragment or islet insulin content released during a 1-h incubation period.

\section{Data analysis}

Data are reported as the means \pm SEM of $n$ experiments. The significance of the differences between means was assessed by analysis of variance followed by Dunnett's test when several experimental groups were compared with the control group. The confidence limit for significance was $5 \%$.

\section{Results}

Figure 1 shows insulin secretion induced by different concentrations of glucose from fragments of pancreas and from isolated islets obtained at different ages. Basal secretion (in the presence of 2.8 or $5.6 \mathrm{mM}$ glucose) was $0.66 \pm 0.08 \%(\mathrm{~N}=20), 0.82 \pm$ $0.09 \%(\mathrm{~N}=25), 0.38 \pm 0.04 \%(\mathrm{~N}=17)$ and $0.88 \pm 0.21 \%(\mathrm{~N}=14)$ of the total pancreas (or islet) content for 19- and 21-day-old fetuses, 3-day-old neonatal rats and 90-dayold adult rats, respectively. Increasing the glucose concentration to 8.3 and $16.7 \mathrm{mM}$ did not alter the basal release of insulin by 19-day-old fetuses. In 21-day-old fetuses, $8.3 \mathrm{mM}$ glucose increased the insulin secretion to $1.16 \pm 0.09 \%(\mathrm{~N}=8)$. At this age, insulin secretion reached $1.26 \pm 0.13 \%(\mathrm{~N}=$ 13) of the total pancreas content in the presence of $16.7 \mathrm{mM}$ glucose $(\mathrm{P}<0.05)$. At 3 days of age, the insulin secretion induced by 8.3 and $16.7 \mathrm{mM}$ glucose was $0.70 \pm 0.17 \%$ $(\mathrm{N}=17)$ and $1.06 \pm 0.23 \%(\mathrm{~N}=6)$ of pancreas content, respectively $(\mathrm{P}<0.05)$. At the same glucose concentrations, the insulin secretion observed for adult islets was $1.83 \pm$

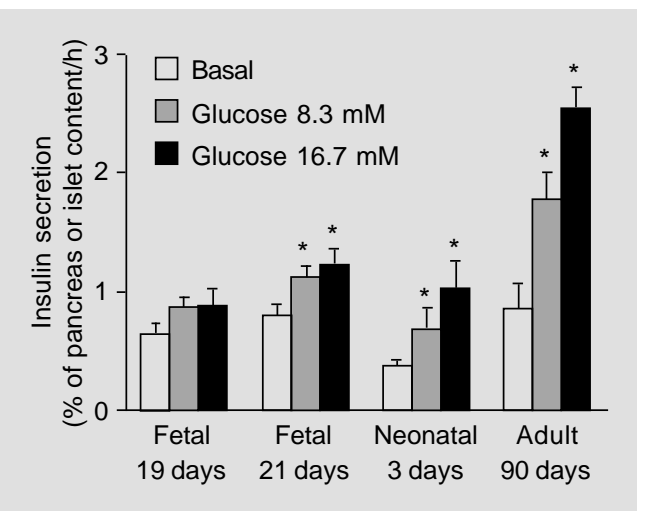

$0.22 \%(\mathrm{~N}=6)$ and $2.62 \pm 0.15 \%(\mathrm{~N}=6)$ of the islet content, respectively $(\mathrm{P}<0.05)$.

Insulin secretion induced by $\mathrm{K}^{+}(30 \mathrm{mM})$ is illustrated in Figure 2. There was a progressive increase in insulin secretion with age. However, no difference from basal secretion $(5.6 \mathrm{mM}$ glucose) was noticed in the fetal groups exposed to $\mathrm{K}^{+}$. In neonatal and adult pancreas insulin secretion induced by $30 \mathrm{mM} \mathrm{K}^{+}$was 1.4- and 2.0-fold greater than basal secretion, respectively.

In the next series of experiments, we analyzed the effect of the nonspecific phosphodiesterase inhibitor theophylline, that increases the intracellular cAMP content, and carbamylcholine, an agonist that stimulates the formation of $\mathrm{IP}_{3}$ and DAG in Bcells. Both theophylline $(5 \mathrm{mM})$ and carbamylcholine $(200 \mu \mathrm{M})$ stimulated insulin secretion at all ages. Insulin secretion in the presence of theophylline was 1.7-fold higher

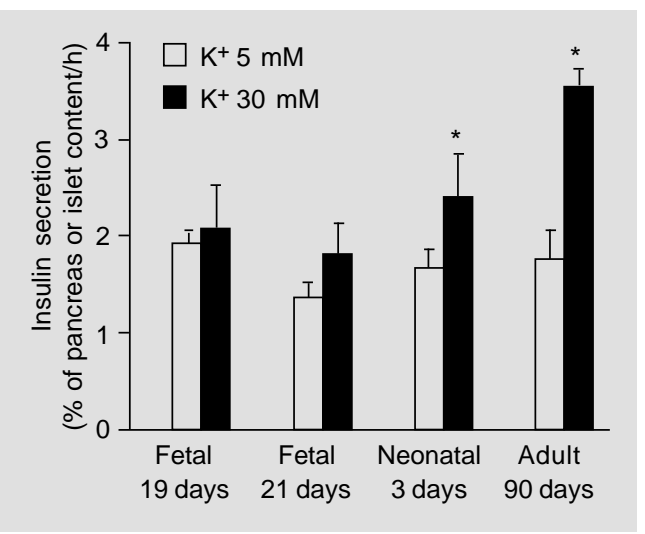

Figure 1 - Effect of 8.3 and 16.7 $\mathrm{mM}$ glucose on insulin secretion. Prior to exposure to different concentrations of glucose, fragments of fetal and neonatal pancreas or adult rat islets were preincubated for $45 \mathrm{~min}$ at $37^{\circ} \mathrm{C}$ in a Krebs-bicarbonate medium containing $5.6 \mathrm{mM}$ glucose. This preincubation medium was then replaced with Krebs-bicarbonate containing the desired concentration of glucose (8.3 or 16.7 $\mathrm{mM})$. The columns represent the cumulative $(1 \mathrm{~h})$ insulin secretion, expressed as percentage of the total fragment or islet content for each glucose concentration. The values are reported as the mean \pm SEM of 6 25 experiments. ${ }^{*} \mathrm{P}<0.05 \mathrm{com}$ pared to basal insulin secretion.

Figure 2 - Effect of $30 \mathrm{mM} \mathrm{K}^{+}$on insulin secretion. Fragments of fetal or neonatal pancreas or adult rat islets were preincubated for $45 \mathrm{~min}$ at $37^{\circ} \mathrm{C}$ in a Krebs-bicarbonate medium containing $5.6 \mathrm{mM}$ glucose. This medium was then replaced with Krebs-bicarbonate containing 30 $\mathrm{mM} \mathrm{K}^{+}$. The osmolarity of the medium was kept constant by withdrawing an equimolar amount of $\mathrm{NaCl}$. The columns represent the cumulative $(1 \mathrm{~h})$ insulin secretion, expressed as percentage of the total fragment or islet content, at each $\mathrm{K}^{+}$concentration. Values are reported as the mean \pm SEM of 6-9 experiments. ${ }^{*} \mathrm{P}<0.05$ compared to insulin secretion with $5 \mathrm{mM}$ $\mathrm{K}^{+}$. 
Figure 3 - Effect of $5 \mathrm{mM}$ theophylline (Theo) and $200 \mu \mathrm{M}$ carbamylcholine (Cch) on insulin secretion. Fragments of fetal and neonatal pancreas or islets from adult rats were preincubated for $45 \mathrm{~min}$ at $37^{\circ} \mathrm{C}$ in Krebs-bicarbonate medium containing 5.6 $\mathrm{mM}$ glucose. This medium was then replaced with Krebs-bicarbonate containing $5 \mathrm{mM}$ theophylline or $200 \mu \mathrm{M}$ carbamylcholine. The columns represent the cumulative $(1 \mathrm{~h})$ insulin secretion, expressed as percentage of the total fragment or islet content. The values are reported as the mean \pm SEM of 6-14 experiments. ${ }^{*} \mathrm{P}<0.05$ compared to basal insulin secretion.

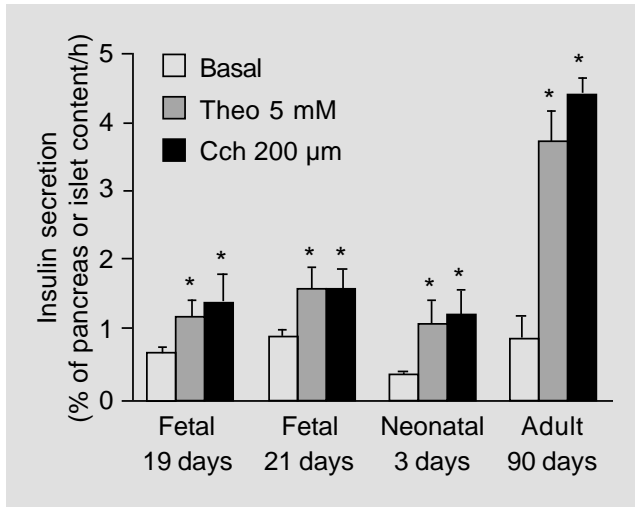

in 19- and 21-day-old fetuses, 2.6-fold higher in 3-day-old rats and 4-fold higher in adult rats than each respective basal secretion (5.6 $\mathrm{mM}$ glucose). In the presence of carbamylcholine the increase in insulin secretion above basal values was 2- and 1.7-fold in 19- and 21-day-old fetuses, 2.9-fold in 3-day-old rats, and 5-fold in adult rats (Figure 3). As observed for supraliminal glucose concentrations and $30 \mathrm{mM} \mathrm{K}^{+}$, the increase in insulin secretion in the presence of theophylline or carbamylcholine was more marked in the pancreas of 3- and 90-day-old rats.

\section{Discussion}

In the perinatal period of life, the mechanism of insulin secretion undergoes a decisive phase of functional maturation (1). During this period, insulin secretion in response to nutrient secretagogues is reduced compared to adulthood (5). In addition, the insulin response to glucose is monophasic and is similar to the pattern observed for insulin secretion during the onset of type 2 diabetes in adult humans. Thus, analysis of the glucose-sensing mechanism in fetal and neonatal islets may contribute to our understanding of the loss of glucose sensitivity associated with type 2 diabetes.

In adult islets, the reduction in $\mathrm{K}^{+}$permeability and the consequent membrane depolarization are important steps in the mechanism of nutrient-induced insulin secretion $(6,14-16)$. The poor secretory response to glucose in fetal and neonatal islets is ascribed to the uncoupling of glucose stimulation and membrane depolarization which results in the opening of an insufficient number of voltage-sensitive $\mathrm{Ca}^{2+}$ channels and only a marginal increase in cytosolic $\mathrm{Ca}^{2+}$ (9). In the present experiments glucose-induced insulin secretion was observed only in the pancreas of 21-day-old fetuses, thus supporting the view that the coupling between glucose metabolism and alterations in membrane potential is not yet fully developed at earlier ages (around 19 days). The observation that high concentrations of $\mathrm{K}^{+}$failed to stimulate insulin secretion in the pancreas of 19-day-old fetuses also indicates that the Bcell plasma membrane is not yet mature enough to undergo sufficient depolarization to provoke the necessary accumulation of cytosolic $\mathrm{Ca}^{2+}$ seen in neonatal B-cells (17). Hence, there is no insulin secretion. In addition to the absence of an adequate signal derived from glucose metabolism $(9,12)$, the poor secretory response to glucose during fetal development may also be ascribed to a reduced and/or altered behavior of $\mathrm{K}^{+}{ }_{\text {ATP }}$ channels (18) associated with unresponsive $\mathrm{Ca}^{2+}$ L-type channels. The latter channels are already present in fetal B-cells, but are not yet sensitive to $\mathrm{Ca}^{2+}$-antagonists (4). We measured the membrane potential of neonatal rat islet cells in the presence of depolarizing concentrations of glucose (Boschero AC, Carroll $\mathrm{P}$ and Atwater I, unpublished data). Only 3 of 23 cells examined depolarized in the presence of tolbutamide, while none depolarized in the presence of glucose. If one assumes that at least the tolbutamide-sensitive cells were B-cells, it becomes clear that glucose was unable to depolarize neonatal B-cells. Thus, these data, together with those discussed above, indicate that the lack of insulin secretion in response to glucose and high $\mathrm{K}^{+}$concentrations probably reflects the sum of different factors, including insufficient membrane depolarization, reduced entry of $\mathrm{Ca}^{2+}$ into B-cells, and hence reduced 
accumulation of cytosolic $\mathrm{Ca}^{2+}$.

Insulin secretion is modulated by second messengers, including cAMP, $\mathrm{IP}_{3}$ and DAG. In B-cells, the intracellular levels of these second messengers can be increased by the stimulation of adenylylcyclase and phospholipase $\mathrm{C}$, respectively. It is well established that both of these pathways are important modulators of insulin secretion in fetal, neonatal, and adult islets (10,19-21). In 19-dayold fetuses, theophylline stimulated insulin secretion, thus confirming that this pathway is already operative at this age and that it is fundamental for insulin secretion during fetal life. The phospholipase $\mathrm{C}-\mathrm{IP}_{3}-\mathrm{DAG}$ pathway was also found in 19-day-old fetuses as judged by the increase in insulin secretion induced by carbamylcholine. However, the rise in insulin secretion provoked by the muscarinic agonist was more marked in neonatal and adult pancreas. The latter observation may be partly explained by the fact that the $\alpha$ isoform of protein kinase $C$, which is important for the second phase of insulin secretion, is detected in islet B-cells only after 3 days of life (22).

In conclusion, the perinatal period of life, which extends from the 21 st day of fetal life to three days after birth, is crucial for the maturation of the insulin-secreting mechanism. Initially, insulin secretion is more dependent on the presence of cAMP and can be potentiated by agents that stimulate $\mathrm{IP}_{3}$ and DAG formation. Subsequently, the adult pattern of insulin secretion involving nutrient metabolism and alterations in $\mathrm{K}^{+}$and $\mathrm{Ca}^{2+}$ permeabilities becomes established. Finally, the mature biphasic insulin response is completed with the development of amplification systems involving the participation of several protein kinase isoforms, especially protein kinase $C_{\alpha}$.

\section{Acknowledgments}

The authors wish to thank Mr. L.D. Teixeira for technical assistance and Dr. S. Hyslop for editorial assistance.

\section{References}

1. Hellerstrom C \& Swenne I (1991). Functional maturation and proliferation of fetal pancreatic B-cells. Diabetes, 40 (Suppl 2): 89-93.

2. Kervran A \& Randon J (1980). Development of insulin release by fetal rat pancreas in vitro: effect of glucose, amino acids and theophylline. Diabetes, 29: 673678.

3. Freinkel $\mathrm{N}$, Lewis $\mathrm{NJ}$, Johnson $\mathrm{R}$, Swenne I, Bone A \& Hellerstrom C (1984). Differential effects of age versus glycemic stimulation on the maturation of insulin stimulus-secretion coupling during culture of fetal rat islet. Diabetes, 33: 1028-1038.

4. Hole RL, Pian-Smith MCM \& Sharp GWG (1988). Development of the biphasic response to glucose in fetal and neonatal rat pancreas. American Journal of Physiology, 254: E167-E174.

5. Bliss CR \& Sharp GWG (1994). Development of glucose responsiveness from the fetal to the adult B-cell. In: Flatt P \& Lenzen $S$ (Editors), Frontiers of Insulin
Secretion and Pancreatic B-Cell Research. Smith-Gordon, Great Britain, 69-76.

6. Boschero AC (1996). Acoplamento da estimulação-secreção de insulina pelas células B pancreáticas. Arquivos Brasileiros de Endocrinologia e Metabologia, 40: 149-155.

7. Prentki M \& Matschinsky FM (1987). $\mathrm{Ca}^{2+}$, cAMP and phospholipids-derived messengers in coupling mechanism of insulin secretion. Physiological Reviews, 67: 1185-1248.

8. Rorsman $\mathrm{P}$, Arkhammar $\mathrm{P}$, Bokvist $\mathrm{K}$, Hellerstrom C, Nilsson T, Welsh M, Welsh $\mathrm{N} \&$ Berggren P-O (1989). Failure of glucose to elicit a normal secretory response in fetal pancreatic beta cells results from glucose insensitivity of the ATP-regulated $\mathrm{K}^{+}$channels. Proceedings of the National Academy of Sciences, USA, 86: 45054509.

9. Black MA, Mealing GRA, Whitfield JF, Schwartz JL \& Bégin-Heick N (1994). Insulin secretion and intracellular $\mathrm{Ca}^{2+}$ rises in monolayer cultures of neonatal rat Bcells. Cellular Signaling, 6: 897-904.

10. Ammon HPT, Glocker $C$, Waldner RG \& Wahl MA (1989). Insulin release from pancreatic islets of fetal rats mediated by leucine $\mathrm{b}-\mathrm{BCH}$, tolbutamide, glibenclamide, arginine, potassium chloride, and theophylline does not require stimulation of $\mathrm{Ca}^{2+}$ net uptake. Cell Calcium, 10:441450.

11. Boschero AC, Tombaccini D \& Atwater I (1988). Effects of glucose on insulin release and ${ }^{86} \mathrm{Rb}$ permeability in cultured neonatal and adult rat islets. FEBS Letters, 236: 375-379.

12. Boschero AC, Bordin S, Sener A \& Malaisse WJ (1990). D-glucose and L-leucine metabolism in neonatal and adult cultured rat pancreatic islets. Molecular and Cellular Endocrinology, 73: 63-71.

13. Scott AM, Atwater I \& Rojas E (1981). A method for the simultaneous measurement of insulin release and B-cell membrane potential in single mouse islets of 
Langerhans. Diabetologia, 21: 470-475.

14. Boschero AC \& Malaisse WJ (1979). Stimulus-secretion coupling of glucoseinduced insulin release. XXIX. Regulation of ${ }^{86} \mathrm{Rb}$ efflux from perifused islets. American Journal of Physiology, 236: E139-E146.

15. Cook DL \& Hales CN (1984). Intracellular ATP directly blocks $\mathrm{K}^{+}$channels in pancreatic B-cells. Nature, 311: 271-273.

16. Ashcroft FM, Harrisom DE \& Ashcroft SJH (1984). Glucose induces closure of single potassium channels in isolated rat pancreatic B-cells. Nature, 312: 446-448.

17. Boschero AC, Bordin S, Plasman P \&
Herchuelz A (1992). Effect of glucose and $\mathrm{K}^{+}$depolarization on cytosolic free $\mathrm{Ca}^{2+}$ in cultured neonatal islets. Hormone and Metabolic Research, 24: 51-52.

18. Boschero AC, Tombaccini $D$, Carneiro EM \& Atwater I (1993). Differences in $\mathrm{K}^{+}$permeability between cultured adult and neonatal rat islets of Langerhans in response to glucose, tolbutamide, diazoxide, and theophylline. Pancreas, 8: 44-49.

19. Lambert $A E$, Kanazawa $Y$, Burr IM, Orci $L$ \& Renold AE (1971). On the role of cyclic AMP in insulin release: I. Overall effects in cultured fetal rat pancreas. Annals of the New York Academy of Sciences, 185:
232-244.

20. Mourmeaux JL, Remacle C \& Henquin JC (1989). Effects of stimulation of adenylate cyclase and protein kinase $C$ on cultured fetal rat B-cells. Endocrinology, 125: 26362644.

21. Tuch BE, Palavidis Z \& Turtle JR (1988). Activators of protein kinase $C$ stimulate insulin secretion from the human fetal pancreas. Pancreas, 3: 675-680.

22. Fletcher DJ \& Ways DK (1991). Age-dependent expression of protein kinase $C$ isoforms in rat islets. Diabetes, 40: 14961503. 